arrangement, however, makes for rapidity and ease of reference.

The text is dogmatic. Too dogmatic where the treatment of pulp loss is concerned. Loss of the special sense organs in the pulp of the finger can never be replaced by a thenar flap. In the rare case where closure by split skin graft or shortening of the distal phalanx do not apply, an island pedicle graft is the only means of restoring anything like normal sensation.

The statement that occupational therapy has very little place to offer in the treatment of minor hand injuries fails to acknowledge the help that a wellequipped centre can provide in re-acclimatising an injured hand to the feel of machinery.

To lay too much stress on points such as these would be unnecessarily carping, since through its didactic approach the book derives much of its value. Equipped with this the Casualty Surgeon cannot go far wrong, and it should help materially to reduce the growing wastage of man-hours resulting from injuries of the hand.

\section{ANTIBIOTICS IN MEDICINE}

British Medical Bulletin, 1960, Vol. I6, No. I, 88 pages. 20 s.

During the past i 5 years the number of clinically useful antibiotics has increased from one, penicillin, to about 15. The newer antibiotics have been discovered almost exclusively by vast efforts and expenditure by the pharmaceutical industry. Their chief aims have been to find substances which will control infections hitherto unresponsive to chemotherapy, to find drugs which will deal with organisms that have become resistant to available antibiotics, and to find less toxic compounds.

The present number of the British Medical Bulletin is a survey of all the important aspects of the antibiotic field and, to indicate its scope, I can do no better than give the titles and authors of all the contributors to this excellent volume.

There is an introduction by the scientific editor, Professor L. P. Garrod. Then follow sections on: Chemistry and classification of antibiotics, by E. P. Abraham and G. G. F. Newton. The nature of the selective toxicity of antibiotics, by $\mathrm{E}$. F. Gale. Drug resistance and mechanisms for its development, by Mr. R. Pollock. The principles of therapeutic use of antibiotics, by L. P. 'Garrod and E. F. Scowen. The laboratory control of antiobiotic therapy, by J. C. Gould. The pharmacology of antibiotics, by J. M. Robson and G. A. H. Buttle. The rationale and management of combined therapy, by B. W. Lacey. Preventive use of antibiotics in medicine, by E. G. L. Bywaters. Preventive use of antibiotics in surgery, by Gerard W. Taylor. The chemotherapy of tuberculosis, with special reference to patients whose bacilli are resistant to the standard drugs, by John Crofton. The treatment of bacterial endocarditis, by A. Eric Dormer. The dangers of antibiotic treatment, by
D. M. Dunlop and J. McC. Murdoch. Clinical problems of drug-resistant pathogens, by E. J. L. Lowbury. Laboratory uses of antibiotics, by Robert Cruickshank. The search for new antibiotics, by A. H. Campbell.

This number of the British Medical Bulletin is an outstanding contribution to the literature and views on antibiotics and should be read by everyone who wants to bring himself up to date in this most important branch of medicine.

\section{EARLY DIAGNOSIS}

By various authors. Edited by Henry Miller, M.D., F.R.C.P. Pp. 400. Edinburgh and London: E. \& S. Livingstone Ltd. $25 \mathrm{~s}$.

This book contains 25 chapters, each written by a different author, and a very good index. It was an excellent idea to invite authors having such widely varying interests to contribute: among them are to be noted two General Practitioners and seven Professors, surely an unusually broad spectrum of authority to be found within the covers of a single volume! Lord Cohen contributes a characteristically vigorous and practical introductory chapter entitled 'On Early Diagnosis' which sets the standard for the book as a whole. In his Preface, Dr. Miller says that it has been written for the general practitioner, who bears special responsibility for the early recognition of important disease. In fact, both junior house officers and consultants will read the book with profit. Such a masterly exposition of sheer clinical sense, for instance, as Professor Dunlop's four pages on the diagnosis of Hyperthyroidism, is hard to equal anywhere.

The essential facts about the early manifestations of a very large number of clinical conditions are given in this book, put in a new and stimulating form, so that even those well acquainted with them will find an interest in this variation of the usual text book presentation. The book may therefore be strongly recommended not only to those engaged in the day-to-day practice of their profession, but to anyone seeking to revise his knowledge or to sharpen his clinical wits - to all clinicians, in fact.

\section{THE FUNCTIONS OF THE ENDOCRINE GLANDS}

By P. F. Hall, M.D., M.R.A.C.P. Pp. 290, figs. 77. Sydney: Horwitz Publications Inc.; London: Pitman Medical Publishing Co. Ltd.; Philadelphia: W. B. Saunders Company.

There has long been a need for a short book of this type, and the author is to be congratulated on the excellent way in which he has dealt with it. This book is not so specialized and abstruse that it cannot be read by the practising clinician with no great knowledge of physiology and endocrinology; it is not packed with so many formulae, references 
and interesting biological facts that it is too long to be of practical value. On the other hand, it is concise, factual and authoritative; essential references are given for those anxious to read more widely and sufficient formulae and diagrams are included to enable structural relationships and hormonal feed-back mechanisms to be readily grasped.

Brief introductory chapters deal with the general problems of endocrinology and the chemistry of hormones. Ten chapters follow, each dealing with a single endocrine gland, prefaced by brief descriptions of the relevant embryology and histology. Three chapters at the end describe Endocrine Factors in Growth, Maturation and Decline, the Nervous Control of the Endocrine Glands and Steroid Metabolism. There is a satisfactory index. The author is Assistant Physician to the Sydney Hospital, and the book has been printed and produced in Australia. The standard of this production is excellent and the printing clear and accurate. This is a very valuable book which deserves a wide success.

\section{THE NEUROLOGIC EXAMINATION}

By Russell N. DeJong, M.D., Professor of Neurology and Chairman of Department of Neurology, University of Michigan Medical School. Second edition. Pp. 1,078. Pitman Medical Publishing Co. Ltd., London. 1958. £7.

In the preface to this large volume, the author writes of his intention to make the work a practical guide to the neurological examination for students and practitioners of medicine. If faced with a guide of such magnitude, any medical student in this country, and most postgraduates for that matter, would undoubtedly decide never to touch neurology. The book is drawn out into a string of simplified anatomical facts and innumerable ' signs ' so beloved by some neurologists, based on the Salpétrière dogma of a past era. These signs were largely popularized in America by Wartenberg, on whose teaching DeJong heavily leans. The fundamentals of neuroanatomy and neurophysiology which are alleged to be incorporated in this book are feeble attempts to provide a basis for the localization of lesions. The scope of the neurophysiology is so limited and so simplified that even first-aid workers would find the account lacking. The specialist turning to this book for specific information will often be disappointed by a text which relentlessly misses that particular point. It is difficult to conceive how any member of the medical profession could read this book with profit and impunity. Although the standard of printing is high and the illustrations are excellent, the text could with advantage be reduced by 800 pages.

\section{DISEASES OF THE NERVOUS SYSTEM}

By Sir Francis Walshe, M.D., D.Sc., F.R.S., with chapters on 'The Neurological Complications of Liver Disease' and 'Hepatolenticular Degeneration' by J. M. WALSHE, M.R.C.P. Ninth edition. Pp. 373. E. \& S. Livingstone Ltd., Edinburgh and London. 1958. 30s.

The impression that this, the ninth edition, is much larger than previous editions is due mainly to the use of thicker paper and not expansion of the text. Two short chapters have, however, been added by Dr. John Walshe and these keep well to the tradition of this book of brevity and clarity.

This textbook of clinical neurology has already been of considerable service to innumerable medical students and as an elementary account of diseases of the nervous system it is difficult to conceive a better.

\section{RECENT ADVANCES IN CEREBRAL PALSY}

Edited by R. S. ILlingworTh, M.D., F.R.C.P., D.P.H., D.C.H. First edition. Pp. 386 . J. \& A. Churchill Ltd., London. I958. 503.

The title of this book leads one to expect a present-day assessment and progress report of the clinical features, pathogenesis, disordered physiology, pathology and treatment of cerebral palsy. Little recent material is presented and very few advances. It is almost entirely from the investigative aspect of a subject that progress is made, and in this book the scientific aspects of cerebral palsy are almost completely ignored. The team of paediatricians, orthopaedic surgeons, psychologists, physiotherapists and speech therapists fail to make progress because they lack a centre-forward (or child neurologist) and several other key positions. Much amateur neurology is thrown around. What does Professor Illingworth mean when, in his opening paragraph on spasticity, he says:' A child is sometimes hypotonic in the earlier months but shows the stretch reflex and increased tendon jerks '? On the whole the American contributors, Courville, Meyers, Perlstein, and Phelps, have written interesting, readable accounts of their varying subjects. Courville's account of the structural changes in the brain in cerebral palsy is excellent and beautifully illustrated, and Meyer's contribution on neurosurgery of cerebral palsy is fascinating though highly controversial.

This subject, which lies between so many branches of medicine, needs some very clear light thrown upon it, and the sooner the scientific aspects of the problem are explored the better will be the expected results in the knowledge of how cerebral palsy is caused and from there, how it can be prevented or treated. 